International Journal of Engineering \& Technology, $7(2.23)(2018) 332-334$
International Journal of Engineering \& Technology
WPC
Website $:$ www.sciencepubco.com/index.php/IJET
Research paper

\title{
Methodology of Efficiency Assessment in the Context of Building Sustainability
}

\author{
Jozef Švajlenka ${ }^{1}$, Mária Kozlovská ${ }^{2}$ \\ ${ }^{1}$ Technical University of Košice, Faculty of Civil Engineering, Department of Construction Technology and Management \\ ${ }^{2}$ Technical University of Košice, Faculty of Civil Engineering, Department of Construction Technology and Management \\ *Corresponding author E-mail:jozef.svajlenka@tuke.sk
}

\begin{abstract}
The construction industry has long been among the sectors with lower productivity and efficiency. In the framework of construction, the concept of sustainability is at the forefront. Basic elements of sustainability are environmental aspects, social and economic aspects associated with construction as such. The basic requirement to measure these factors is to set the criterions and draft a methodology for their evaluation. The aim of this paper is to present a methodology for assessing the effectiveness of buildings in the context of sustainability. The article also presents a preview of the evaluation of two wood-based construction technologies through the proposed efficiency assessment methodology in the context of building sustainability.
\end{abstract}

Keywords: Assessment, Building, Efficiency, Sustainability, Wood

\section{Introduction}

In the context of growing shortage of building capacities and of qualified human resources in particular, innovative solutions are being sought and applied even in areas where the established, albeit not necessarily efficient, procedures have been preferred $[1,2]$.

According to Kupkovič [3], efficiency is a synthetic and heterogeneous concept. Syntheticity manifests itself in the fact that the concept of efficiency comprises a substantial portion of the problems of a society's economic development, ranging from the discovery and use of resources (labour, work instruments and work artefacts), their transformation into utility artefacts, to their distribution (consumption) [4,5]. The heterogeneous character of the concept of efficiency shows in its multiplicity of meanings [6]. In actual practice, it is applied in various contexts. According to Kupkovič [3], efficiency, in a broader sense, can also be understood as successful production activity arising from implementing new technology or organisation of work, consistency of production and product quality, improved consumption standards, eliminating strenuous labour, etc [5,7]. Efficiency therefore conveys new qualitative elements of economic and manufacturing activities [8]. According to Pifko, Špaček et al. [9], efficiency is a ratio of incurred costs (construction funding, effort and time expended) to gained benefits (quality and comfort).

According to Vlachynský and Markovič [10], measuring efficiency presupposes a statement of criteria and selection of indicators. According to Sosedová [11], a criterion is a measure, rule or a 'standard' by means of which efficiency levels can be determined, that is, to what extent a given solution meets the requirements stemming from economic, social and environmental interests in the society, and hence from the basic aspects of sustainability. The criteria for judging efficiency may vary, as efficiency an aggregate measure of all factors which affect the results of any activity $[5,6]$. They depend on specific conditions and goals in terms of which an efficiency assessment is performed. An efficiency criterion must be identified according to specific intentions and conditions $[12,13]$. An efficiency criterion is expressed by means of indicators. A choice of a criterion involves the setting of a goal, and we therefore need to pay sufficient attention to it. As a result of this, a criterion also serves as a means of discovering and exploiting reserves and forms a basis for measuring efficiency [14,15].

The significance of efficiency indicators, according to Maříková and Mařík [16], also lies in the fact that they can be used in comparing the efficiency of different variants. Indicators allow measuring the degree of fulfilling a criterion's requirement, determining the size and cause of deviations and proposing a method of their elimination [17].

According to Huttmanová [18] and Mederly [19], sustainability is currently reflected in almost every area of life [20,21]. Many previously assessed development and growth aspects have recently been extended to include the dimension of sustainability. However, development sustainability itself is relatively hard to define. Evaluating specific production and implementation processes in terms of sustainability is a complex process [22,23]. The objective of the sustainability assessment is to identify more appropriate development options that will not limit the future needs of humanity. In principe is a matter of finding a new, 'healthier' type of progress which is more appropriate in terms of sustainability principles. This new type of progress was defined as a state of global balance in which the global population and capital are maintained at a more or less constant level, while trends affecting the increase or decrease of these variables must be thoroughly kept under control $[4,24,25]$. 


\section{Material and Methods}

Basic elements of sustainability are environmental aspects, social and economic aspects associated with construction as such. The basic requirement to measure these factors is to set the criterions and draft a methodology for their evaluation.

Based on a comparison of generally defined formulations of efficiency, relation (1) was established to evaluate and demonstrate wooden buildings' construction systems' efficiency, determining efficiency as a ratio of synthetic to analytic efficiency indicators expressed in terms of an efficiency index (within the considered interval). Efficiency measurement in our case is a ratio of gained benefits (by means of evaluating sustainability, the so-called sustainability index, quality and comfort of living, expressed as a synthetic indicator) to incurred costs and time required for acquisition (acquisition costs, operating costs and construction time, expressed as analytic indicators). For the sake of unification, data used in the efficiency analysis will be recalculated as percentage points. A percentage point is a unit of arithmetic difference between two values stated as percentages. It is a dimensionless number stating an increase or a decrease in the value in question in terms of hundredths of their relative value in relation to their reference value.

$E_{i}=\frac{\mathrm{SI}_{\mathrm{i}}}{\mathrm{TC}_{\mathrm{i}}+\mathrm{AC}_{\mathrm{i}}+\mathrm{OC}_{\mathrm{i}}}$

where:

$\mathrm{Ei}$ - Efficiency of construction system (Efficiency of construction system - Ei) [efficiency index]

SIi - sustainability index of construction system 'i' recalculated as percentage points

$\mathrm{CTi}$ - average construction time of construction system 'i' recalculated as percentage points

$\mathrm{ACi}$ - average acquisition costs calculated per $\mathrm{m} 2$ of useful area of construction system ' $i$ ' recalculated as percentage points

OCi - average monthly operating costs for heating calculated per $\mathrm{m} 2$ of useful area of construction system 'i' recalculated as percentage points

Based on the analysis of different system evaluations (STN EN 15978, 15643-3, 15643-4, LEED, BREEAM, DGNB and SBTooL [26-31]), evaluation criteria for the established assessment methodology were selected (Table 1).

Table 1: Analysis and selection of criteria for selected system evaluations.

\begin{tabular}{|c|c|c|}
\hline \multicolumn{3}{|c|}{ SUSTAINABILITY OF BUILDINGS } \\
\hline $\begin{array}{l}\text { In the environmental } \\
\text { field, }\end{array}$ & In the social field, it is & In the $\frac{\text { economic field }}{\text { is assessed }}$ it \\
\hline $\begin{array}{l}\checkmark \text { materials used for } \\
\text { construction } 1,7\end{array}$ & $\begin{array}{c}\checkmark \text { visual comfort in the con- } \\
\text { struction's interior }{ }^{2,4,5,6,7,8} \\
\checkmark \text { visual comfort of the con- } \\
\text { struction's exterior }{ }^{2,4,5,6,7} \\
\checkmark \quad \text { layout }^{2,7} \\
\checkmark \quad \text { quality of living in the } \\
\text { construction } \\
2,7 \\
\checkmark \quad \text { construction health safety } \\
2,4,5,6,7\end{array}$ & $\begin{array}{c}\checkmark \quad \text { investment costs for } \\
\text { procurement of bui- } \\
\text { lding } 3,7 \\
\checkmark \text { operating costs } 3,4 \text {, } \\
5,6,7,8\end{array}$ \\
\hline
\end{tabular}

\begin{tabular}{|c|c|}
\hline $\begin{array}{c}\checkmark \text { acoustic comfort in the construction } \\
2,4,5,6,7,8 \\
\checkmark \text { lighting comfort in the construction } \\
2,4,5,6,7,8 \\
\checkmark \text { air quality in the construction's } 2,4, \\
5,6,7,8\end{array}$ & $\begin{array}{c}\checkmark \text { overall construction build quality }{ }^{2,3} \\
\checkmark \text { occurrence of defects at the be- } \\
\text { ginning of the construction's use }{ }^{2,3} \\
\checkmark \text { occurrence of defects during the } \\
\text { construction's use }{ }^{2,3}\end{array}$ \\
\hline $\begin{array}{cc} & \checkmark \quad \text { const } \\
\checkmark & \text { thermal comfort } i \\
\checkmark & \text { thermal comfort in }\end{array}$ & $\begin{array}{l}1,2,3 \\
\text { period }^{2,4,5,6,7,8}\end{array}$ \\
\hline
\end{tabular}
Note: Evaluation systems $-{ }^{1}$ STN EN 15978, ${ }^{2}$ STN EN 15643-3, ${ }^{3}$ STN EN 15643-4, ${ }^{4}$ LEED, ${ }^{5}$ BREEAM, ${ }^{6}$ DGNB,${ }^{7}$ SBToolCZ,${ }^{8}$ CESBA Tool SK
The above user parameters formed a basis for measuring construction efficiency, or efficiency of construction systems based on wood, and will also help to discover any imperfections in the individual construction sustainability criteria. Efficiency measurement is evaluated using specified criteria. Synthetic (sustainability criteria, so-called sustainability index, quality and comfort of living) and analytic (acquisition costs, operating costs and construction time) efficiency indicators will offer the possibility to compare several construction types of wood constructions and their degree of efficiency in a context with parameters and sustainability itself.

\section{Results}

\section{Model example of the evaluation result}

The individual representatives of the investigated buildings evaluated the questionnaire on their construction and housing survey. A total of 126 wooden buildings were evaluated.

The questionnaire also examined the previous housing of the respondents, where $60.3 \%$ of the respondents stated that their previous housing was in a panel house, and $27.8 \%$ of the respondents said they were living in a traditional brick house and $11.9 \%$ were in a wood-based building. Such representation and experience of individual respondents provide a good signal for their valid comparison of current and previous housing.

Examined buildings have been used in the largest range of 2 to 10 years, but there have also been buildings that have been used for over ten years.

For the analysis, we selected two design systems on which we present the methodology proposed for our assessment of efficiency in the context of sustainability.

Log Construction System (traditional construction system) ( 25 buildings)

- Column Construction System (35 buildings)

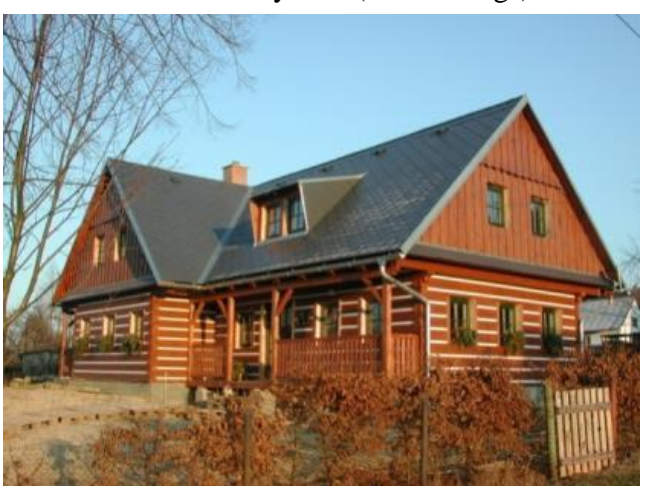

Fig. 1: Example of log construction

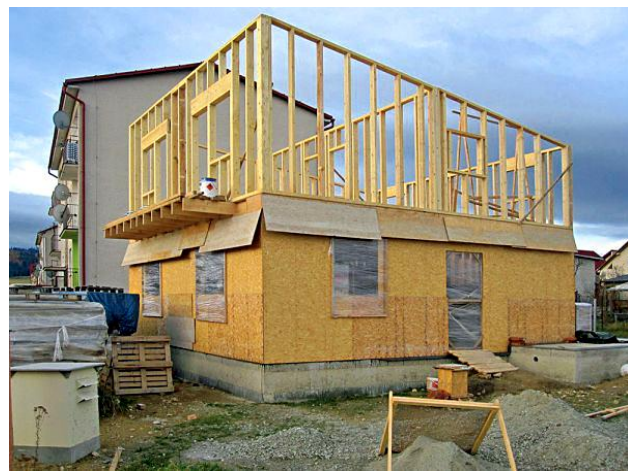

Fig. 2: Example of column construction system 
Table 2: Efficiency of the compared wood constructions' construction systems with equal weights of evaluated criteria, expressed in terms of an efficiency index

\begin{tabular}{|c|c|c|c|c|c|c|}
\hline \multirow{2}{*}{$\begin{array}{c}\text { Construction } \\
\text { system }\end{array}$} & \multicolumn{2}{|c|}{$\begin{array}{c}\text { Execution by a } \\
\text { supplier firm }\end{array}$} & \multicolumn{2}{c|}{ DIY execution } & \multicolumn{2}{c|}{$\begin{array}{c}\text { A combination of } \\
\text { execution methods }\end{array}$} \\
\cline { 2 - 7 } & $\begin{array}{c}\text { Energy- } \\
\text { efficient }\end{array}$ & $\begin{array}{c}\text { Low-energy } \\
\text { house }\end{array}$ & $\begin{array}{c}\text { Energy- } \\
\text { efficient }\end{array}$ & $\begin{array}{c}\text { Low-energy } \\
\text { house }\end{array}$ & $\begin{array}{c}\text { Energy- } \\
\text { efficient }\end{array}$ & $\begin{array}{c}\text { Low-energy } \\
\text { house }\end{array}$ \\
\hline CS & 0.572 & 0.608 & 0.400 & 0.418 & 0.357 & 0.370 \\
\hline LS & 0.445 & 0.459 & 0.310 & 0.317 & - & - \\
\hline
\end{tabular}

Note: PS - Panel construction system, CS - Column construction system, LS - Log construction system.

$$
0,7
$$

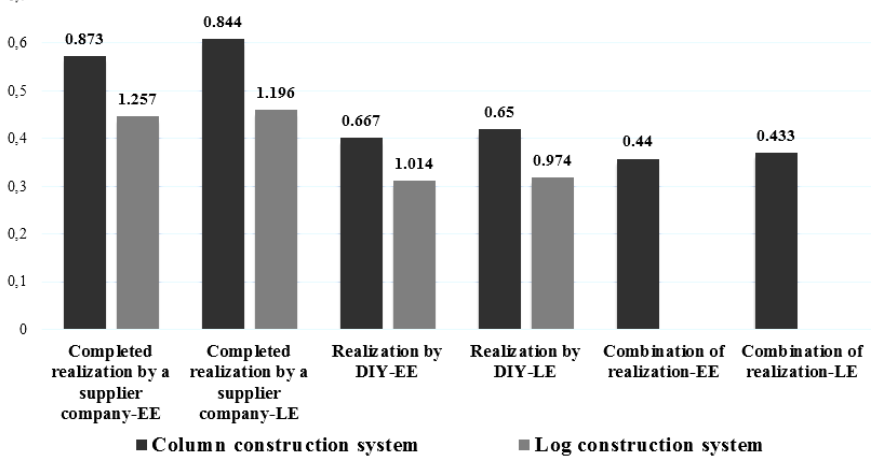

Fig. 3: Efficiency of the compared wood constructions' construction systems

The conclusions drawn from the individual variants show that: constructions where there was a combined execution method are the least efficient (a combination of execution by a supplier firm and DIY execution),

- DIY execution was not as efficient as execution by a supplier firm, although it was still more efficient than a combined execution method,

- $\quad$ in terms of energy standards, execution by a supplier firm achieved the highest efficiency, but in the case of DIY execution and a combined method, the resulting efficiency is comparable,

- a higher energy standard, as opposed to an energy-efficient one, was only reflected in a moderate increase in efficiency.

\section{Conclusion}

The presented work addresses, to a limited extent, the problems of assembled constructions based on wood in the context of construction efficiency and sustainability. The opening part of the work was dedicated to introducing efficiency at a general level in relation to construction, sustainability in the context of construction, modern construction methods and wood constructions' potential in the context of sustainability and efficiency. The analysis of the current situation clearly highlighted the need to increase construction efficiency and sustainability globally. Modern methods of construction are also a response to this trend, as these methods offer efficient processes of construction design and execution, resulting in larger production volumes in higher quality and shorter acquisition time. Their objective is to increase construction efficiency through customer satisfaction, shortened construction time, quality improvement, sustainability and reduction of the environmental impact of the construction itself. By applying modern, efficient technological solutions, combined with suitable environmental materials and processes, it is possible to accomplish such a sustainability vision.

\section{Acknowledgement}

This contribution is a partial output of the VEGA - 1/0557/18 "Research and development of process and product innovations of modern methods of construction in the context of the Industry 4.0 principles" project solution.

\section{References}

[1] ECEEE (European Council for an Energy Efficient Economy), "Products covered and their status in the EuP Process", ECEE, Stockholm, (2013).

[2] Ecorys, Ecofys and BioIntelligence, Study to Support the Impact Assessment for the EU Energy Saving Action Plan, (2010).

[3] Kupkovič M Ekonomický podnikový slovník, Vydavatel'stvo Ekonomickej Univerzity, Bratislava, (1994).

[4] IEA (International Energy Agency, Technology Roadmap - Energy efficient building envelopes. OECD, (2013).

[5] Alchian AA, Demsetz H (1972) Production, Information Costs, and Economic Organization, Am Econ Rev 62 (5), 777-795.

[6] Ruuska A, Häkkinen T (2016) Efficiency in the delivery of multi-story timber buildings, Energy Procedia 96, 190 - 201.

[7] Pifko H. NEED - Navrhovanie energeticky efektívnych domov, Vydavatel'stvo Eurostav, Bratislava, (2017).

[8] Gašparik J, Gašparík M (2012) Automated quality excellence evaluation. Gerontechnology 11 (2), 84.

[9] Pifko H, Špaček R. Efektívne bývanie, Vydavatel'stvo Eurostav, Bratislava, (2008)

[10] Vlachynský K, Markovič P. Finančné inžinierstvo, Vydavatel'stvo Ekonómia, Bratislava, (2001).

[11] Sosedová J. Towards efficiency in Logistics Parks, Acta Logistica Moravica, (2013).

[12] Finch G. Energy Efficient Building Enclosure Design Guidelines for Wood-Frame Buildings, RDH Building Engineering Ltd, (2013).

[13] Minarovičová K, Antošová N. (2016) Sustainability of ETICS maintenance technologies, Applied Mechanics and Materials: Advanced Architectural Design and Construction 820:194-199.

[14] Gibberd J. (2014) Sustainability impacts of building products: An assessment methodology for developing countries, Acta Structilia 21 (2), 69-84.

[15] Pošiváková T, Hromada R, Veszelits Laktičová K, Vargová M, Pošivák J, Molnár L. (2018) Selected Aspects of Integrated Environmental Management, Ann Agr Env Med.

[16] Maříková P, Mařík M. Moderní metody hodnocení výkonnosti a oceňování podniku, Vydavatelství EKOPRESS, Prague, (2005).

[17] Zuo J, Zhao ZY. (2014) Green building research - current status and future agenda: A review, Renew Sust Energ Rev 30, 271-281.

[18] Huttmanová E. Selected aspects and problems of evaluation of sustainable development. http://www.pulib.sk/elpub2/FM/Kotulic14/pdf_doc/11.pdf , 2017 (accessed 2 October 2017).

[19] Mederly P. Environmentálne indikátory trvalo udržatelného rozvoja. Dissertation thesis, (2009)

[20] Tambouratzis T. (2016) Analysing the construction of the environmental sustainability index 2005, Int J Environ Sci Technol 13, 2817-2836.

[21] Korytárová J, Hromádka V, Dufek Z. (2012) Large city circle road Brno. Organ Technol Manag Constr Int J 2012, 3, 584-592.

[22] Jain RK, Taylor JE, Peschiera G. (2012) Assessing eco-feedback interface usage and design to drive energy efficiency in buildings, Energ Buildings 48, 8-17.

[23] Lupisek A, Nehasilova M, Mancik S, Zelezna J, Ruzicka J, Fiala C, Tywoniak J, Hajek P. (2017) Desighn strategies of building with low embodied energy. P I Civil Eng-Eng Su 170(2):65-80.

[24] Zgutova K, Decky M, Sramek J, Dreveny I. (2015) Using of Alternative Methods at Earthworks Quality Control. World multidisciplinary earth sciences symposium, WMESS 2015, 15:263-270.

[25] Sebok T, Vondruska M, Kulisek K. (2001) Influence of MSFC-type dispersant composition on the performance of soluble anhydrite binders. Cement Concrete Res 31(11):1593-1599.

[26] EN 15643-3: (2012) Sustainability of Construction Works - Assessment of Buildings - Part 3: Framework for the assessment of social performance, prepared by CEN/TC 350/WG 5 .

[27] EN 15643-4: (2012) Sustainability of Construction Works - Assessment of Buildings - Part 4: Framework for the assessment of economic performance, prepared by CEN/TC 350/WG 4.

[28] STN 730540 Tepelnotechnické vlastnosti stavebných konštrukcii a budov. Tepelná ochrana budov. Bratislava: SÚTN (2002).

[29] STN EN 15643-3. (2012) Sustainability of Construction. Assessment of Buildings. Part 3: Framework for Assessing Social Performance.

[30] STN EN 15643-4. (2012) Sustainability of Construction. Assessment of Buildings. Part 4: A Framework for Assessing Economic Characteristics.

[31] STN EN 15978. (2012) Sustainability of Construction. Assessment of the Environmental Performance of Buildings. Calculation Methods. 